\title{
Morphology of an Infundibulum of the Oviduct of the Sexually Mature Hens
}

\author{
Morfología de un Infundibulum del Oviducto de las Gallinas Sexualmente Madurasvo
}

R. Y. Khokhlov

\begin{abstract}
KHOKHLOV, R. Y. Morphology of an infundibulum of the oviduct of the sexually mature hens. Int. J. Morphol., 26(4):883-886, 2008.
SUMMARY: Studied functional morphology of an infundibulum oviduct of the hens in an age interval 150-540 days. As indicators of development the following parameters served: length, weight, diameter of a infundibulum, sizes epithelial cells, height and width folds of a tunica mucosa, histological structure of a wall of a infundibulum. The results show dynamical increase of investigated parameters with 150- till 360-day's age, with their subsequent decrease to 540-day's age.
\end{abstract}

KEY WORDS: Oviduct; Reproductive system,; Morphology; Layer.

\section{INTRODUCTION}

Morphology of birds genitals during development studied Traynis (1968), Litovchenko (1971), Vernerova \& Burda (1985), Sharandak (1985, 1987, 1988), Jigalova \& Pilipenko (1988), Czareva (1990), Kelany et al. (1992), Yoshimura \& Ogawa (1998), Williams \& Ames (2004).

As is known, the oviduct of the hens in a cranialventralis direction are following departments: infundibulum, magnum, isthmus, shell-gland and excretory section (vagina). The precise border is present only between magnum and isthmus. They are precisely differentiated from each other through circular transparent, without glands a cavity (Tekhver, 1965).

The cranial edge of infundibulum forms protrusion it is lip of an infundibulum extended in dorsoventral direction (Romanoff \& Romanoff, 1949). This department on the basis of morphofunctional features divide into an own infundibulum and it cervix (Richardson, 1935; Aitken \& Johuston, 1963). The tunica mucosa infundibulum is having not glands, it is cover of longitudinal folds, reminding on the pits. Epithelium in this part of an infundibulum consists basically of ciliated cell. In the cervix of infundibulum occur glandulae tubariae, which are especially numerous in end of an infundibulum and partially mix up with groups glands of magnum.

Earlier reports (Krok, 1962; Fedorova, 1987) at the intensively in-lay hen the infundibulum has length $4-7 \mathrm{~cm}$.
Structural organization and functional activity of bodies as a whole and oviduct in particular can be correctly understand only at exact knowledge macro-and micromorphology.

The difficult aspects of features of functional morphology of reproductive system of a home bird are in initial stages of the decision. Therefore our attention was inverted on study of formation of oviduct of the hens, which further provides their high-grade efficiency.

\section{MATERIAL AND METHOD}

The material for research were the Lohmann Brown hens in 150-, 180-, 210-, 360-, 570- day's age. Object of research was served infundibulum of the oviduct. For research were selected 6 hens, which alive weight was within the limits of $5 \%$ from average value of alive weight of general set $(n=100)$ in the certain age.

The hens were killed by decapitation. Anatomic dissection of the birds spent on a technique Komarov (1981). Preparation oviduct was spent under stereoscopic microscope MBS-9. The oviduct was excised. Were determined the borders of departments infundibulum and followed by weighing on weights of the stamp Adventurer AR-3130. Length of infundibulum was defined with the 
help wax sewing. Then a known site sewing measured by a ruler.

For histological observations licks of infundibulum fixing in liquid Carnoy. After fixing tissues were dehydrated and embedded in paraffin. Sections of 5-8 $\mu \mathrm{m}$ thickness were stained with hematoxylin and eosin. Sections were examined under a light microscope Micros MS-300. On histological sections defined height epithelial cell, height and width of a folds of tunica mucosa, relative area of structural elements of an infundibulum wall with the help of a technique of the point calculation by Glagolev (1941) with use graticule by Aftandilov.

\section{RESULTS}

Weight of a infundibulum in 150-day's age has made $0.87 \pm 0.14 \mathrm{gm}$, that makes $1.79 \%$ from weight oviduct and 0,049\% from alive weight the chicken. Length of a infundibulum has made $9.0 \pm 0.7 \mathrm{~cm}$ or $11.6 \%$ from total length oviduct. The diameter infundibulum is equal $7.0 \pm 0.7 \mathrm{~cm}$.

The tunica mucosa of infundibulum oviduct of the 150-day's hens forms longitudinal folds. The tunica mucosa are cover cylindrical ciliary, which height $12.9 \pm 0.8$ $\mu \mathrm{m}$. Height folds of a tunica mucosa in this department is fit with $116.1 \pm 13.4 \mu \mathrm{m}$. Width folds of a tunica mucosa is equal $47.2 \pm 3.1 \mu \mathrm{m}$. In the infundibulum of the 150-day's hens on a share of a tunica mucosa it is account for $64.47 \pm 1.11 \%$, muscular $27.34 \pm 4.22 \%$, serous $8.19 \pm 0.70$ $\%$. In structure of a tunica mucosa the layer epithelial occupy $26.95 \pm 1.28 \%$, connective tissue membrane $35.14 \pm 1.13 \%$, glandular structures $2.38 \%$.

At 180-day's age weight of a infundibulum has made $0.87 \pm 0.16 \mathrm{gm}$ that makes $1.66 \%$ from weight of oviduct and $0.05 \%$ from alive weight a bird. The length of a infundibulum has made $9.2 \pm 0.2 \mathrm{~cm}$, that makes 10.77 $\%$ from length of the oviduct. The diameter of a infundibulum has made $7.8 \pm 0.4 \mathrm{~cm}$.

Height layer epithelial of a tunica mucosa of a infundibulum in this age interval has made $18.5 \pm 0.6 \mu \mathrm{m}$. Height folds of a tunica mucosa of a infundibulum has increased by 2 times and has made $234.2 \pm 15.7 \mu \mathrm{m}$. Width folds of a mucous environment has increased more than in 2 times and has folds $105.5 \pm 10.9 \mu \mathrm{m}$. In the infundibulum of oviduct of the 180-day's hens on a share of a tunica mucosa it is account $49.13 \pm 2.74 \%$, muscular $43.07 \pm 8.64 \%$, serous $7.79 \pm 0.80 \%$. In the structure a tunica mucosa of a infundibulum of oviduct the layer epithelial occupy $20.99 \pm 4.61 \%$, connective tissue membrane $25.76 \pm 2.70 \%$, on a share of glandular structures $2.38 \pm 0.92 \%$.

At 210-day's age weight of a infundibulum 1.0 \pm 0.3 gm, that makes $1.68 \%$ from weight of oviduct and 0.05 $\%$ from alive weight of the hens. Length of a infundibulum has $9.7 \pm 0.8 \mathrm{~cm}$, that makes $10.84 \%$ from length of oviduct. A diameter of a infundibulum has $8.2 \pm 0.2 \mathrm{~cm}$. Height of epithelium of a tunica mucosa of a infundibulum oviduct is equal $16.2 \pm 0.8 \mu \mathrm{m}$. Height folds of a mucous environment of a infundibulum has increased almost in 4 times and has made 921.6 \pm 35.4 $\mu \mathrm{m}$. Width folds of a tunica mucosa of a infundibulum of the oviduct has increased in 2.2 times and has made $230.8 \pm 9.8 \mu \mathrm{m}$. On a share of a tunica mucosa it is account $75.92 \pm 2.82 \%$, muscular $16.20 \pm 5.43 \%$ and serous $7.87 \pm 4.86 \%$. In a the tunica mucosa the layer epithelial occupy $39.81 \pm 2.84 \%$, connective tissue membrane $31.94 \pm 4.51 \%$, on a share of the glandular structures it is account $4.17 \pm 1.12 \%$.

At 360-day's age weight of a infundibulum has increased on $0.1 \mathrm{gm}$ and has made $1.1 \pm 0.1 \mathrm{gm}$, or on 1.53 $\%$ and $0.04 \%$, accordingly, from weight of oviduct and alive weight of the hens. Length of a infundibulum has increased in comparison with 210-day's age on $0.2 \mathrm{~cm}$ and is equal $9.9 \mathrm{~cm}$ or $11.1 \%$ from length of oviduct. The diameter of a infundibulum has made $9.0 \pm 0.7 \mathrm{~cm}$. Height epithelial cell makes $16.9 \pm 0.7 \mu \mathrm{m}$. Height folds of a tunica mucosa is equal $946.4 \pm 51.3 \mu \mathrm{m}$. Width folds of a tunica mucosa has made $251.4 \pm 11.3 \mu \mathrm{m}$. On a share of a tunica mucosa it is account $64.32 \pm 5.37 \%$, muscular $33.12 \pm 1.51$ $\%$, serous $2.56 \pm 0.11 \%$. In the structure of a tunica mucosa on a share epithelium it is account $25.72 \pm 1.21 \%$, connective tissue membrane $30.5 \pm 2.45 \%$, the glandular structures occupy $8.1 \pm 0.38 \%$.

Weight of the infundibulum 540-day's age is equal $1.4 \pm 0.1 \mathrm{gm}$, that makes $1.62 \%$ from oviduct weight and $0.08 \%$ from alive weight a bird. Length of a infundibulum is equal $10.7 \pm 0.5 \mathrm{~cm}$, that makes $12.4 \%$ from total length of oviduct. A diameter of a infundibulum has $9.7 \pm 0.4 \mathrm{~cm}$. Height of epithelium of a tunica mucosa of a infundibulum has made $10.0 \pm 0.5 \mu \mathrm{m}$. Height folds of a tunica mucosa has $146.8 \pm 16.2 \mu \mathrm{m}$. Width of folds has made $33.8 \pm 2.1$ $\mu \mathrm{m}$. On a share of a tunica mucosa it is account $65.88 \pm 2.16$ $\%$, muscular $26.75 \pm 1.27 \%$, serous $7.38 \pm 0.61 \%$. In a tunica mucosa of a infundibulum the layer epithelial occupy $24.37 \pm 1.90 \%$, connective tissue membrane $36.35 \pm 2.40 \%$, on the glandular structures it is account $5.16 \pm 1.20 \%$. 


\section{DISCUSSION}

Our researches cover two periods of postnatal ontogenesis of the oviduct: 1) period "the intensive development of oviduct" and 2) period "the stable functioning of oviduct".

The period of intensive development of oviduct begins with 150-day's age and lasts up to 180-day's. The given period is characterized by intensive increase of weight, length and thickness of a wall of oviduct, differentiation of oviduct on departments. The second period proceeds from 210-day's age to 540-day's is characterized by a stable morphofunctional condition of oviduct.

During the period 150-540 days length of a infundibulum has increased on $18,9 \%$. Relative length of a infundibulum during the same period insignificantly changed thus in 150-day's age this parameter is fixed by greatest. Least relative length of a infundibulum is marked in 210-day's age. It is necessary to note, that dynamics of length of a infundibulum changes synchronously with total length of oviduct in the investigated period.

Analyzing dynamics of weight of a infundibulum we shall note, that this parameter for the analyzed period has increased by $61 \%$, while weight itself oviduct, for the same interval of time, has increased by $76 \%$. The greatest gain of weight of a infundibulum is marked during 360540 days $-27 \%$. As for to relative weight of a infundibulum to total weight of oviduct, the greatest meaning of this parameter is fixed to 150-day's age. Least relative weight of a infundibulum has appeared in 360day's age.

Analyzing dynamics of relative weight of a infundibulum to alive weight of the hens we shall note, that the least meaning of this parameter in 360-day's age, and maximal in 540-day's, and in an interval 360-540 days relative weight of a infundibulum to alive weight of the hens has increased in 2 times.

Histological research of a infundibulum have shown, that the tunica mucosa of a infundibulum thinwall, make up fine folds and cover by ciliary cylindrical epithelium. Epithelial cells the infundibulum can be divided into two groups: ciliary and mucous (goblet cells). The sizes epithelial cells for the period of research change within the limits of $10-18 \mu \mathrm{m}$, that is predetermined by a functional condition of a organ as a whole and infundibulum in particular.

In a foundation folds of a infundibulum are lie the friable connecting tissue, rich by blood vessels. Analyzing changes of height folds of a tunica mucosa, it is necessary to note, that it, since 150-day's till 360-day's age is intensively increased, and greatest up of this parameter occurs during 180-210 days, when height folds has increased almost in 4 times. In the following age period 210-360 days the meaning of this parameter is stabilized, with the subsequent prompt reduction of height folds of a tunica mucosa to 540-day's age up to a level of a beginning oviposition (150 days).

As for to width folds of a tunica mucosa, the changes of meanings of this parameter have the same tendency, as well as height folds. Namely, during 150210 days width folds has increased almost in 5 times and to 540-day's age corresponded to meaning of a beginning of research.

The analysis of structure of a wall of a infundibulum shows, that the greatest place, for the period of research, is occupy by a tunica mucosa, on its share it is account on the average $64 \%$. On a share muscular and serous of environments it is account $29 \%$ and $7 \%$, accordingly. Muscular the layer of a infundibulum is submitted by fasciculi smooth muscle cell. Serous tunic thin has folds, blood vessels and nervous plexuses.

KHOKHLOV, R. Y. Morfología de un infundibulum del oviducto de las gallinas sexualmente maduras. Int. J. Morphol., 26(4):883-886, 2008.

RESUMEN: Se estudió la morfología funcional del infundíbulum del oviducto de gallinas en un intervalo de edad de 150-540 días. Sirvieron como indicadores de desarrollo los siguientes parámetros: longitud, peso, diámetro del infundíbulum, tamaño de las células epiteliales, altura y ancho de los pliegues de la túnica mucosa y estructura histológica de la pared del infundíbulum. Los resultados muestran incrementos dinámicos de los parámetros investigados con 150 días hasta 360 días de edad, con su posterior disminución a los 540 días de edad.

PALABRAS CLAVE: Oviducto; Sistema reproductor; Morfología; Capa. 


\section{REFERENCES}

Aitken, R. N. C. \& Johuston, H. S. Observations on the fine structure of the infundibulum of the avian oviduct. $J$. Anat., 97(1):87-90, 1963.

Czareva, O. Y. Features of morphology and histochemistry gland of a tunica mucosa of various departments of the oviduct of the hens. Omsk, 49:51, 1990.

Fedorova, N. N. Growth and development of reproductive system of hens of breed white leghorn, grown up at various light modes. Age morphology of an internal of glands of agricultural animals at various technology of animal industry. The collection of proceedings (interdepartmental) MVA, 37-40, 1987.

Glagolev, A. A. Geometrical methods of the quantitative analysis of units under microscope. Lvov, 1941. 263 pp.

Jigalova, E. E. \& Pilipenko, M. E. Age morphologies of organs ovogenesis a turkey. Morphologists of Ukraine to agriculture, Kiev, 1988. pp.33-4.

Kelany, A. M.; el-Shamy, S. A.; Abou-Elmagd, A.; Selim, A. A.; Kamel, G. \& el-Bab, M. R. F. Studies on the development of the oviduct in high and low eggproducing fowl. Assiut veter. med. J., 28(55):93-106, 1992.

Komarov, A. V. Anatomical dissection and studying of features of a structure of a body poultry. Latvian Agricultural Academy, Elgava, 1981. p.19.

Krok, G. S. A microscopic structure of organ of birds with bases embryology. Morphologists of Ukraine to agriculture, Kiev, 1962. p.187.

Litovchenko, L. N. Morphofunctional feature of ovary and oviduct in connection with age and breed of the hens. Morphologists of Ukraine to agriculture, Kharkov, 1971. p.189.

Richardson, K. C. The secretory phenomena in the oviduct of the fowl, including the process of shell formation examined by microinceration technique. Philos. Trans., 3(225):56-7, 1935.

Romanoff, A. L. \& Romanoff, A. J. The Avian Egg. Wiley, New York-London, 1949. pp.173-252.

Sharandak, V. I. Breeds and age features of oviduct morphology of the hens. Morphologists of Ukraine to agriculture. Kiev, 149-50, 1988.

Sharandak, V. I. Morphology of oviduct of the hens in age, breed and functional aspects. Age morphology internal of animals at different technologies. Animal industries, 1987. pp.40-4.

Sharandak, V. I. Some breeds of feature skeletal muscle and oviduct of the hens //Morphological features of domestic animal and birds. The book of abstract of Ukrainian agriculture Academy, Kiev, 1985. pp.70-3.

Tekhver, Y. T. Histology of poultry. Estonian agricultural Academy, Tartu, 1965. p.75.

Traynis, K. V. Electron microscopy research secretion of fiber, polysaccharide and keratin in epithelial crates oviduct of the hens. Archive AGE, 55(10):17-21, 1968.

Vernerova, E. \& Burda, Z. Srovnani morfometri oviduct during late oviposition in a small passerine bird. Exp. Biol., 20:26-8, 1985.

Williams, T. D. \& Ames, C. E. Top-down regression of the avian oviduct during late oviposition in a small passerine bird. J. Exp. Biol., 207(2):263-8, 2004.

Yoshimura, Y. \& Ogawa, H. Histological characterization of the oviducal structures in guinea fowl (Numida meleagris). Japan Poultry Sci., 35(3):149-56, 1998.

Correspondence to:

Khokhlov Roman Yurievich

Penza State Agricultural Academy

Russian Federation

4400014 st.

Botanicheskaja, 30

Penza

RUSSIA

Telephone: (8412)699139

(8412)629390

Cell phone: 89063982333

Email: roman_kh@rambler.ru

Received: 01-09-2008

Accepted: 02-10-2008 